occupy about a third of the daylight hours with such flighting, for no reason as yet discovered other than joie de vivre. As the author repeatedly shows that there was a large slice of sheer delight in his painstaking and often dawn to dusk watches, the rapport between author and subject matter is again striking.

This is essentially a book to be dipped into rather than read consecutively. Inevitably there is a good deal of overlap between chapters which are derived from the same series of observations even if they largely correspond with the heads of information which the author considers to be basic for a proper understanding of any diurnal bird of prey general habits, detailed daily behaviour, food preferences, hunting methods, breeding behaviour and population dynamics. The claim is made and probably justified that, under these heads as a whole, more is known of the fish eagle than of any other African bird of prey. But the gaps are always admitted and how Leslie Brown himself would have loved to try to fill them! But as he presciently admits in the very last sentence of the book - 'I will not have the time or the energy to do it properly any more.'

The 144-page volume is embellished by eleven well-produced colour-plates, which beautifully portray particular aspects of behaviour. A similar number of black and white illustrations are less satisfactorily reproduced. For the student taking up the author's challenge, the mass of data on which the book is founded is conveniently assembled in 6 maps, 10 figures and 20 tables.

HUGH F. I. ELLIOTT

\title{
Camouflage and Mimicry, by Denis Owen; Feeding Strategy, by Jennifer Owen; Sexual Strategy, by Tim Halliday. Oxford UP, £6.95 each.
}

These three volumes of a new series, Survival in the Wild, each consider a biological activity essential to living organisms if they are to survive and reproduce, and they examine in detail the physical and behavioural adaptations that have been evolved.

Denis Owen deals with what he calls 'the tangled web of deception' practised by many groups of animals but most strikingly by insects. Animals may be camouflaged by colouring or shape and often by a combination of both. Or they may deliberately set out - as wasps do - to draw attention to themselves with bold colouring to warn possible predators that they are unpalatable or even dangerous. More subtle are the mimics, species which, although possibly edible and harmless, have evolved resemblances to the original boldly coloured individuals and so bluff predators into leaving them alone. The author describes the almost incredible manifestations of these strange deceptions, some from his own researches on several families of African butterflies.

In Feeding Strategy Jennifer Owen examines first the different sources of food and feeding methods, and then describes how animals have evolved different ways of exploiting them. Herbivores can graze, chew and suck plants and feed on flowers, fruits and seeds. Carnivores, in addition to straightforward predation by hunting can filter-feed (strikingly demonstrated by some of the great whales), live parasitically, or eat dead plants and animals. Finally, there is an interesting chapter on special feeding relationships such as courtship feeding, parental care, food sharing in social insects, symbiosis and commensalism - 'eating at the same table'.

Tim Halliday soon explodes the myth that reproduction is a cooperative venture by male and female in the perpetuation of the species. Many examples are given, other than the well-known ones such as spiders, of the frequent hostility between male and female, before, during and after mating. The author examines some of the biological principles that are involved in the sexual behaviour of animals under several headings including mating systems, finding and choosing mates and mating itself. In this book, as in the previous one, man is put in his rightful place as an animal and his strategies considered objectively.

The three books provide excellent up-to-date introductions to their subjects, enhanced by examples from each author's researches in the field or laboratory. All are well illustrated with 32 pages of excellent colour photographs and 60 black and white illustrations in photograph and line, and they have useful glossaries and lists of further 
books to read. They can be read pleasurably by the general reader.

JOHN CLEGG

\section{The Peregrine Falcon, by Derek Ratcliffe. Poyser, $£ 12$.}

Derek Ratcliffe, an undoubted and critical scientist, has been as enthusiastic as any amateur in his life-long and deep interest in the peregrine, and much of his work with the Nature Conservancy and related bodies has been researching environmental problems which either directly or indirectly affect the peregrine. All this has resulted in a 400-page readable volume.

After describing the peregrine's changing fortunes - protected, persecuted and poisoned - the author surveys its present habitat, distribution and numbers, concluding that there are few parts of Britain and Ireland in which it could not live, given the chance, for at least some part of the year. The chapter on food and feeding habits is fascinating, not only because of the description of food taken, hunting efficiency, food wastage and calculations of speed attained in a stoop, but because in Ratcliffe's writing you sense the thrill that comes from watching these aerial manoeuvres. In a chapter on population and dynamics he reviews the peregrine's past and present status which is, in part, linked to the pesticide story, of which he gives a full account. Here his own detective work on thinning egg shells resulted in important disclosures. Incidentally, he comments forcefully on the failure of the Pesticide Safety Precaution Scheme to publish any report in the last 12 years.

The peregrine is regarded as an ecological barometer, being the terminal focus of energy in a wildlife community, and in his final chapter Ratcliffe looks at its future as it runs the gauntlet of egg-thieves, pet-keepers and the threat of increased acres of Forestry Commission conifers. He concludes that pesticides are the bird's biggest problem, and, if that can be overcome, the peregrine, aided by a growing number of sympathisers, probably faces a brighter future than many birds and other animals.

The book is illustrated by four fine watercolours and a series of black and white pictures by Donald Watson, and more than 60 photographs. It is an example of what a good monograph should be: readable, well produced and good value.

PETER CONDER

\section{Monarchs of the Glen, by Duff Hart-Davies.Cape, $£ 1.95$. Highland Wildlife, by Richard Perry. Croom Helm, £6.95.}

Monarchs of the Glen, written with love and knowledge, takes us back to the earliest days of the Caledonian Forest, liberally covered with ancient pines and harbouring bears, beaver and wolves as well as red deer, more akin in size to English park stags. But as the author points out, trees are not essential to a forest (derived from the Latin foris, or outside), which is uncultivated land set apart for sport, usually deer.

The monstrous evictions from 1780-1830 were caused by the introduction of sheep and the simultaneous collapse of the kelp industry. Their reign was short-lived, however, for by 1870 the economy of $3 \frac{1}{2}$ million acres of the Highlands was that of the deer forest. Probably not more than 1800 people gained their living therby, but as early as 1850 the custom of letting stalking had arrived. Until fairly recently, most stalking was done by rich landowners; but nowadays more and more letting is by the stag rather than the season, allowing many more people to participate, including foreigners.

Most proprietors try to shoot selectively (though it's hard to deprive a foreigner of his one and only chance), thanks to the invaluable work done by the Nature Conservancy on Rhum; and there is unlimited demand for venison in Germany. This is as well since only deer have the stamina to produce protein out of marginal, albeit beautiful, land. Therefore the growth of deer farming is predictable. Yet, given good fencing, this need not affect stalking's future for, as the author points out: 'Once the stalker has set foot on the hill, he is just as dependent on his legs, his wind and his wits as were his Victorian predecessors. Like them, he is alone with the grouse, the eagles and the deer. 